TITLE:

\title{
ECOLOGICAL DISTRIBUTION OF EPIPHYTIC HYDROZOA WITH SPECIAL REFERENCE TO SERTULARELLA MIURENSIS
}

\author{
$\operatorname{AUTHOR}(\mathrm{S})$ :
}

Nishihira, Moritaka

\section{CITATION:}

Nishihira, Moritaka. ECOLOGICAL DISTRIBUTION OF EPIPHYTIC HYDROZOA WITH SPECIAL REFERENCE TO SERTULARELLA MIURENSIS. PUBLICATIONS OF THE SETO MARINE BIOLOGICAL LABORATORY 1973, 20: 401-418

\section{ISSUE DATE:}

1973-12-19

URL:

http://hdl.handle.net/2433/175768

RIGHT: 


\title{
ECOLOGICAL DISTRIBUTION OF EPIPHYTIC HYDROZOA WITH SPECIAL REFERENCE TO SERTULARELLA MIURENSIS ${ }^{1,2)}$
}

\author{
MORITAKA NISHIHIRA \\ Department of Biology, University of the Ryukyus, Naha City, Okinawa, Japan
}

With 7 Text-figures

The range of ecological distribution of epiphytic Hydrozoa on the shore is not spread throughout the potential range decided by their tolerance to abiotic environmental factors in physiological sense. This actual distribution may be decided through the interactions between Hydrozoa and the physicochemical environmental factors, and other organisms. The mechanisms involved in this problem will generally be considered based on the studies carried out at Asamushi Marine Biological Station. Sertularella miurensis STECHOW, a thecate hydroid, is most abundant in the area concerned, consequently the description will be done mostly on this species.

The general account of the shore of Asamushi and vicinity is given by HosHIAI (1965).

\section{Epiphytic Hydrozoa and Algal Substrata:}

Hydrozoa are observed attaching to various materials such as rocks, stones and boulders, wooden structures, shells and carapaces, ascidian tests, annelid tubes, bryozoans, other hydroids and algae, etc. They could be grouped roughly into 3 main groups in relation to algal substrata, namely 1: Hydrozoa which colonize non-algal substrata, 2: those colonize algae and other materials, and 3: those epiphytize only algae (NiSHIHIRA, 1965). Groups 2 and 3 comprise the epiphytic Hydrozoa.

The association between Hydrozoa and algae could be classified into 2, namely direct and indirect ones. The former is formed by the settlement of larvae onto the associated algal thallus and the latter by the growth of colonies from other substratum to the associated alga. Most of the epiphytic Hydrozoa seemed to be of the former type. The latter comprises only the minor portion of the population. The discussion, therefore, will be limited to the direct association.

Algae as the Substratum of Hydrozoa:

In Asamushi area, 80 species of algae (including 2 of Zosteraceae) were examined

1) Contributions from the Marine Biological Station of Asamushi, Aomori Ken, No. 407.

2) Contributions from the Sesoko Marine Science Laboratory, No. 3. 
and 40 were epiphytized by 18 species of Hydrozoa. Among them two (18.2\% of all green algae examined) species were green algae, $14(51.9 \%)$ were brown and $22(59.5 \%)$ were red algae. Most of the associations $(60 \%)$ observed were those between hydroids and Sargasso algae (NishiHIRA, 1965). In the coral reef area of Okinawa the preferability of Sargassaceae was also recognized (NishiHiRA, unpublished). Cystoseira and Sargassum spp. were epiphytized densely. Unfavourability of green algae was also seen. But some species such as Halimeda spp. commonly supported hydroids. In Australian waters, SHEPHERD and WATSON (1970) reported that the red algae as a group are most favourable substrata for hydroids, and except three species, brown algae are generally unfavourable and green algae never seem to bear hydroids. They attributed the general absence of epiphytes on brown algae to the presence of tannic substances secreted by their tissue as reported by ConOver and SiEBURTH (1964) and Sieburth and Conover (1965). But the quantitative analysis of Asamushi data showed that the brown algae, especially those of Sargassaceae, are the most favourable, in 14 species out of 27 algae examined, 17 species out of 18 hydroids were observed, while on 22 species out of 37 red algae examined only 10 species of hydroids were observed. A similar tendency is also reported in epiphytic Bryozoa (RoGICK and Croasdale, 1949, Ryland, 1962).

In general shrub-like algae, those having hard thallus with many rugous and irregular surfaces, those having not so slimy surface offer good substratum (RoGICK and Croasdale, 1949, Ryland, 1962, Nishinira, 1965, 1966, 1967a, Shepherd and WATSON, 1970). More detailed discussion about the problem was already given (NishiHiRA, 1967a, 1968a,b).

On Tsuchiya coast near Asamushi Marine Biological Station, most of the epiphytic hydroids have their own preferable alga and so the distribution is well associated with that of their respective preferable alga. Algal thallus which is not utilized as energy source by hydroids is important as the habitat of hydroids.

\section{Upper Limit of Littoral Distribution:}

FOSTER $(1971 \mathrm{a}, \mathrm{b})$ demonstrated that the range of larval settlement of barnacles extended higher than the surviving adults but the upper limit of adult distribution is lowered by the death from desiccation during tidal emersion. ConNell (1961a,b, 1970) also attributed the delimitation of upper limit in barnacles to the desiccation death. In the case of epiphytic hydroids the same principle may be applied (NISHIHIRA, 1967b). To test this some brief observations were conducted in the field condition.

a. Larval supply: The larvae of Sertularella miurensis is of creeping type (KAKINUMA, 1961). However they disperse rather widely according to the water movement to the deeper sandy bottom with no algal growth and to the midlittoral zone (NISHIHIRA, 1967b). This fact is important for the discussion of the delimitation of the upper limit. If the settled larvae survived and grew in the midlittoral zone many colonies 
would be observed. But in practice there are not. In the tide pool, however, many colonies on Sargassum tortile are commonly observable.

b. Seasonal change of survival rate of Sertularella miurensis in the upper fringe of distribution: The level of low water spring tides varies seasonally. From April to June the low water spring tides occur in the daytime and from November to March at night (Fig. 1). During lower low water spring tides the upper fringe of the Sar. tortile zone emerges. If the effects of emersion are responsible for the delimitation of the upward distribution, colonies on those Sar. tortile must be damaged. In order to ascertain it, algae were sampled seasonally and the rate of living polyps was noted.

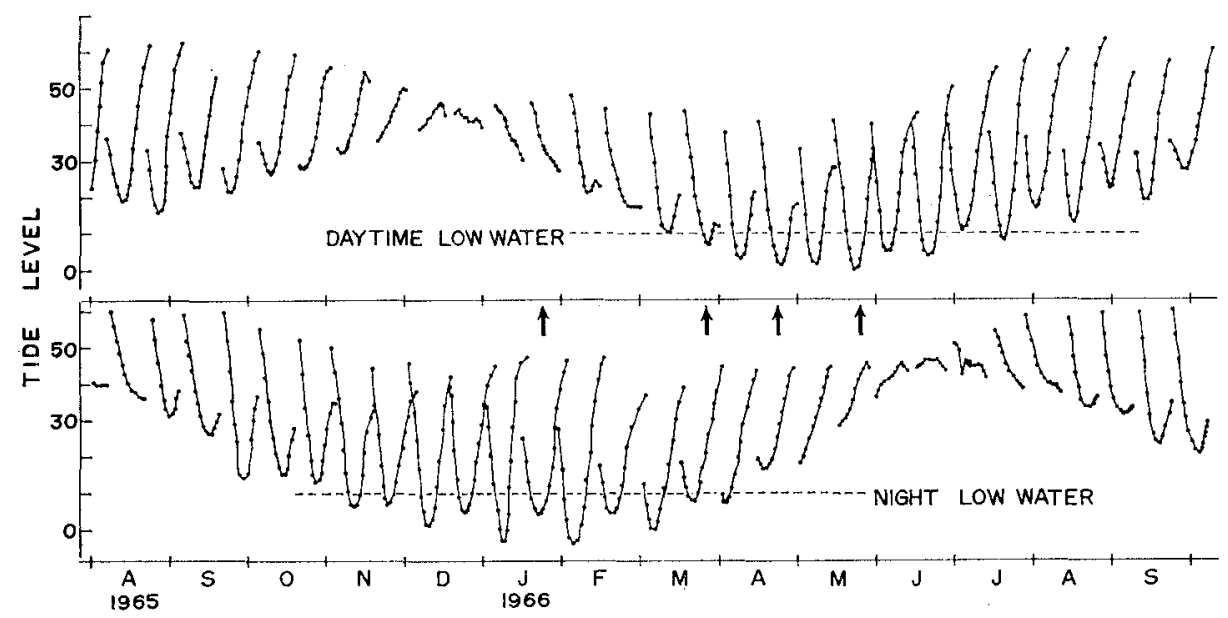

Fig. 1. Seasonal change of the low tide levels in Asamushi area for 1965/1966. Above: daytime low water level, below: night low water level. Broken lines indicate the upper limit of Sargassum tortile and arrows the time of sampling (in Fig. 2 and 3).

The results are summarized in Fig. 2, for late March (3A), late April (4A, B, C) and late May $(5 \mathrm{~A})$. The letters (A, B and $\mathrm{C}$ ) represent the growing sites and degree of emersion of the alga. Ten uprights were sampled at random from each $5 \mathrm{~cm}$ of the main branch from base to tip of the thallus. The solid hydrothecae were treated as living polyps and empty ones as dead. Until Feburary the survival rate is fairly high probably because the algae are not emersed in the daytime. Those colonies under continuous submergence were very healthy over the whole length of algal thallus throughout the year (NishinIRA, 1968c, Table 1). Emersion in the daytime seems to be critical to the survival of hydroid in every example from March to May (Fig. 2). The degree of damage is dependent on the level of low water, the growing position of the alga and the posture of the alga at low tide or during exposure to the direct sunlight. In March (3A) only proximal part of the alga emerged and about a half of the polyps in this position were dead, the mortality is larger at the proximal part. In April the 

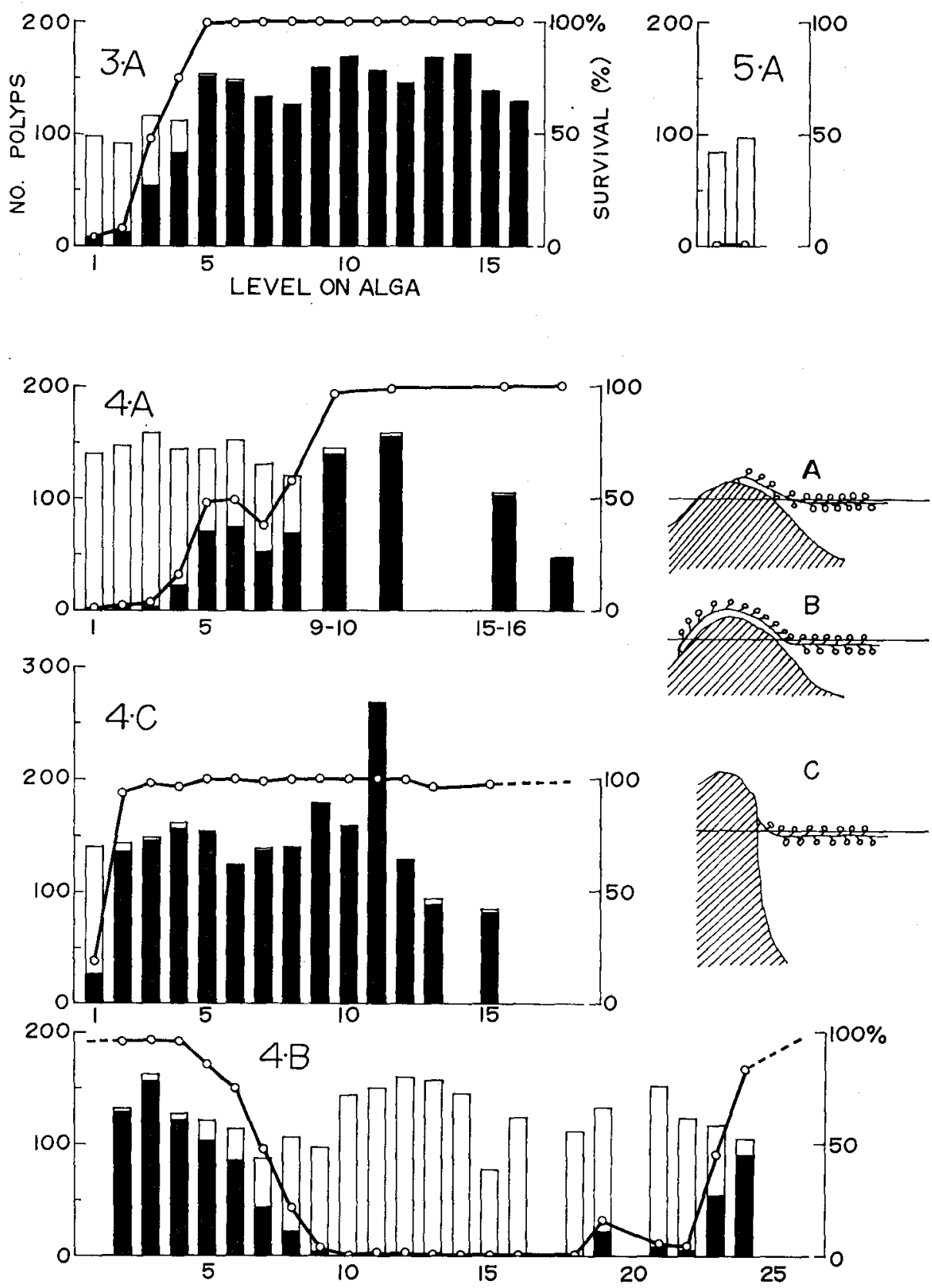

Fig. 2. Rate of living polyps of Sertularella miurensis colonizing Sargassum tortile growing around the upper fringe of distribution. Ten uprights were sampled at random in each $5 \mathrm{~cm}$ level of the main branch from base to distal part of the thallus, and number of solid (black histgram) and open (or dead, open histogram) polyps were counted. 3: late March, 4: late April, 5: late May. $\mathrm{A}, \mathrm{B}$ and $\mathrm{C}$ indicate the growing position of Sargassum tortile. For further explanation see text. 
tide level decreased further, and the emerged portion expanded than in March at the same level on the shore and hence resulted in the wider range of the influenced portion (4A). In April, other two thalli growing in the different positions were observed. The results also suggested the strong emersion effect on the survival of polyps (4B and C). It was difficult to collect the alga at the same level in May, since the algae were detached because of the greater emersion in April and early May, when the effect of sunlight became stronger. Occasionally the proximal part of the main branches remained even in May, but attached colonies were all dead (5A).

These observations suggest that emersion in the daytime is leathal for hydroids attaching to Sar. tortile. Unlike Sargassum thunbergii, this alga does not make a dense carpet in the lower littoral, therefore the colonies dry up rather rapidly when

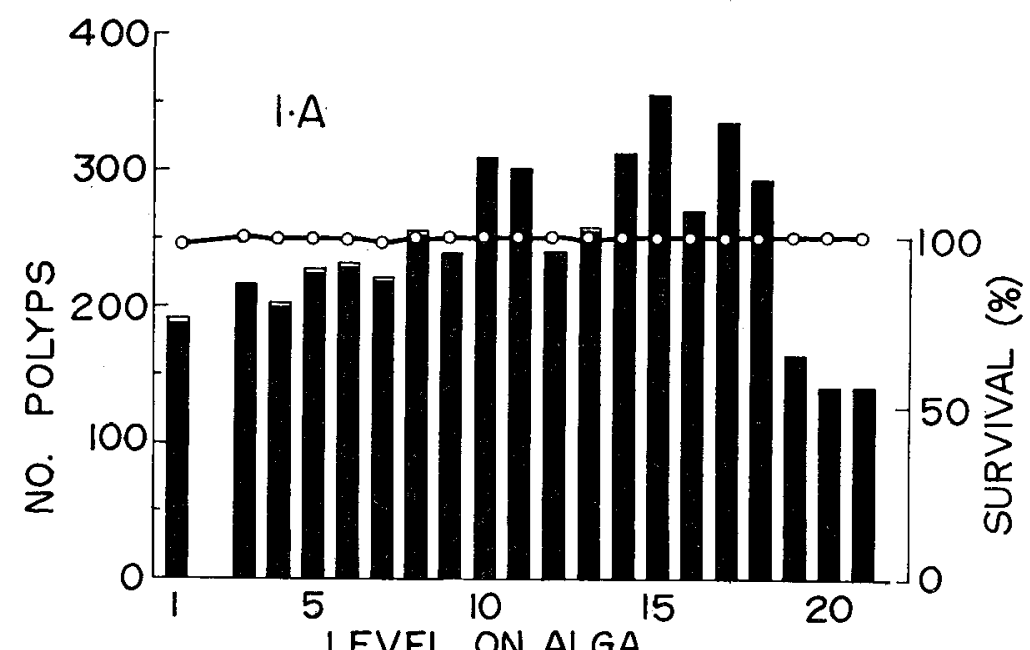

Fig. 3. Rate of living polyps of Sertularella miurensis attaching to Sargassum tortile growing in the upper fringe of distribution in late January. For further explanation see Fig. 2.

Table 1. Average rate of living polyps of Sertularella miurensis epiphytizing Sargassum tortile growing around the upper fringe of distribution.

Ten uprights were sampled in each $5 \mathrm{~cm}$ level of the thallus from base to tip of the plants. Note the high survival rate of polyps in contrast to the results shown in Fig. 2.

\begin{tabular}{lccclc}
\hline \hline Month & Emersion & Height of alga & $\begin{array}{l}\text { Polyps/10 uprights } \\
\text { average (range) }\end{array}$ & $\begin{array}{l}\text { Polyps } \\
\text { dead/alive }\end{array}$ & $\begin{array}{l}\text { Survival } \\
(\%)\end{array}$ \\
\hline November & night & $110 \mathrm{~cm}$ & $135.2(105-170)$ & $0 / 2703$ & 100 \\
December & night & $100 \mathrm{~cm}$ & $129.0(27-162)$ & $3 / 2322$ & 99.87 \\
February & night & $120 \mathrm{~cm}$ & $107.7(69-138)$ & $1 / 2355$ & 99.96 \\
August & none & $20 \mathrm{~cm}$ & $14.5(12-17)$ & $1 / 58$ & 100 \\
September & none & $35 \mathrm{~cm}$ & $12.4(10-18)$ & $0 / 87$ & 100 \\
October & none & $70 \mathrm{~cm}$ & $82.5(52-114)$ & $1 / 1074$ & 99.91 \\
\hline
\end{tabular}


exposed to direct sunlight. Of course an equivalent low water level does occur from November to March, but it occurs at hight (Fig. 1). This seems not to affect the survival of hydroids. The results of January observation is shown in Fig. 3, and of other months in Table 1. Hydroids were healthy in all of these observations.

c. Transplantation experiments: One species of hydroid actually inhabits the midlittoral zone colonizing the proximal part of Sar. thunbergii (NISHIHIRA, 1965, 1966, 1967b, 1968c). This is Sertularella sp. The colonizing position on the thallus is of great importance since when a damp situation is maintained during low water hydroids can grow even in the midlittoral zone. This alga is potentially preferable for Ser. miurensis (NISHIHIRA, 1967a), but in practice only Sertularella sp. is abundant on this alga. In fact this alga, when growing on a vertical rock surface or other situations where the thallus is kept submerged at low tide, often carries abundant Ser. miurensis (Fig. 4). This alga, in these conditions, often covered by the luxuriant growths of Ser. miurensis, Orthopyxis platycarpa and even of Coryne uchidai (NisHmirra, 1971). The difference in survival value of the distal and proximal parts of this alga was investigated by observing the survival of the colonies transplanted to both of them (Fig. 5). Twenty healthy colonies of Ser. miurensis were prepared from submerged Sar. tortile and a set of 5 colonies were transplanted to each of four conditions, namely 1: continuously submerged Sar. tortile in a small channel running across the Sar.

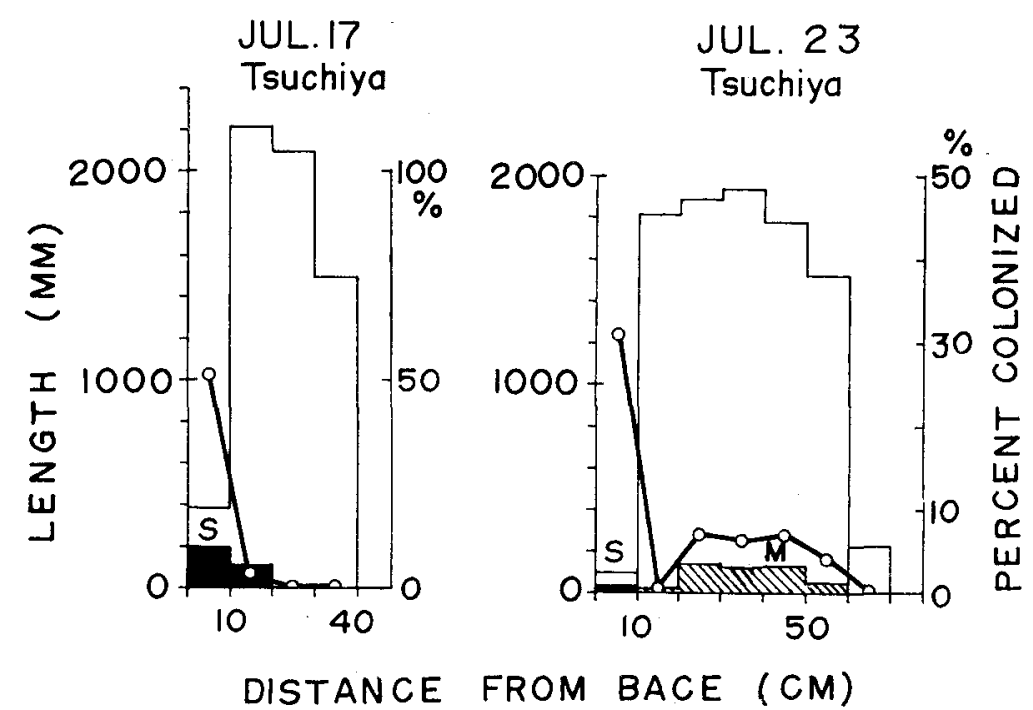

Fig. 4. Colonization pattern of hydroids on the thalus of Sargassum thunbergii. left: the typical Sargassum thunbergii forming the capret in the midlittoral zone. right: Sargassum thunbergii distal part of which is submerged continuously. S: Sertularella sp., M: Sertularella miurensis. 

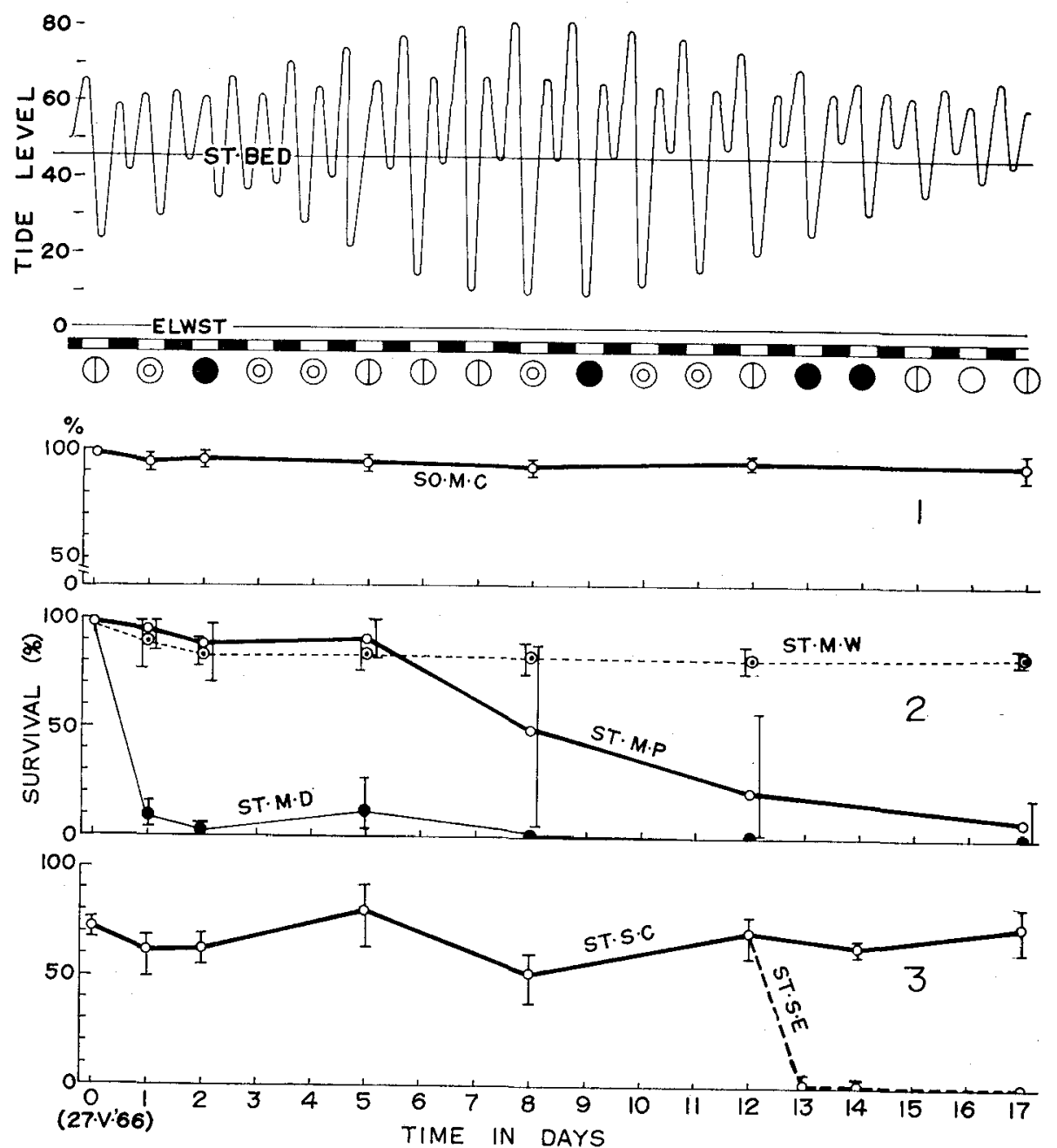

Fig. 5. Survivourship curve of the polyps of Sertularella miurensis transplanted to various situations (1 and 2) and of Sertularella sp. epiphytizing the proximal part of Sargassum thunbergii (3). Above: the tidal behaviour and weather condition during field experiemnts. Horizontal line (ST. BED) indicates the mean level of Sargassum thunbergii bed. White and black bars indicate day and night. All the transplantation were done within $1 \mathrm{~m}^{2}$. Weather: (D): fine, (O): cloudy, : rainy. Below: survival rate of polyps, SO: Sargassum tortile, ST: Sargassum thunbergii, M: Sertularella miurensis, S: Sertularella sp. C: Control, P: transplanted to the proximal portion of alga, D: transplanted to the distal portion of alga, $\mathrm{E}$ : distal portion of algal thallus was removed and thus the proximal portion was exposed to direct sunlight.

thunbergii bed as a control (1, SO-M-C in Fig. 5), 2: proximal part of Sar. thunbergii (2, ST-M-W) in the pool, 3: proximal part of the main branch of Sar. thunbergii (2, ST-M-P) and 4: distal part of Sar. thunbergii (2, ST-M-D). The last three were in the Sar. thunbergii bed, midlittoral zone. At intervals 10 uprights were sampled from each 
of 5 colonies in each situation and the survival of polyps was examined as shown previously. In addition, ten uprights were sampled from each of 5 colonies of Sertularella sp. from the proximal part of Sar. thunbergii (3, ST-S-C). After 12 days the algae were cut off at about $10 \mathrm{~cm}$ from the holdfast and the distal parts were removed. In this situation the survival of Sertularella sp. was also examined (3, ST-S-E). All the results are shown in Fig. 5 together with the tidal rhythm and weather conditions during the field experiments.

In submerged conditions the survival was fairly good (1). Colonies in the small pool declined to $85 \%$ survival in two days but after that showed no fluctuation throughout the experimental period. Actually even in the midlittoral zone. Sar. tortile in pools supports many Ser. miurensis. Although the ST-M-P colonies showed fairly high survival until the 5 th day, the dead polyps gradually increased thereafter. This coincided with the lowering of the low tide level in the daytime hours. On the contrary, in ST-M-D colonies, almost all polyps died after one day and after the 8 th day none were alive. This strengthens the validity of the assumption of the cause of death of Ser. miurensis on Sar. tortile in spring (Fig. 2), and suggests a reason why this hydroid is absent on the thallus of Sar. thunbergii, which is potentially preferable. It is interesting to note that in Sertularella sp. the colonies of ST-S-C showed a high survival rate $(50-80 \%)$ probably because the proximal part was kept damp by the covering by algae. This was confirmed by the sudden death of ST-S-E colonies. This hydroid is small.

In such a manner, emersion effect is of great importance especially for animals which are delicate and susceptible to the desiccation. As some other intertidal animals the upper limit of the distribution of hydroids may be decided by their torelance to severe environments associated with emersion. NAGAO (1965) said that in Akkeshi Bay, colonies of Tubularia venusta are abundant on the rocky shore. They grow actively from May to October. From November to April most of hydranths fall off and there remain only empty stems and resting stolon. The decapitation tends to take place gradually from the high tidal line to the low tidal line along with the succession of the tide.' The similar observations was done in Coryne pusila? attaching to rocks in the lower littoral in Katsura jima island in Miyagi Prefecture. Outside the possible range, of course, even suitable algae do not support epiphytes (CRISP and WILLIAMS, 1963, RYLAND, 1962, NiSHIHIRA, 1967a).

Ecological Distribution of Epiphytic Hydroids and Algal Selection of Settling Larvae in the Sublittoral Zone:

Hydroids as a group distribute over the wide range of salinity conditions, but within a given area of similar salinity condition most hydroids showed marked preference for particular weeds and hence good accordance in ecological distribution with their respective preferable algae (NishiniRA, 1968c). For example, on the rocky shore, Sar. tortile grows in sublittoral zone and epiphytized by abundant Ser. miurensis, 
Sar. hemiphyllum flourishes around the low water mark and colonized preferentially by Orthopyxis platycarpa, and Sar. thunbergii in the midlittoral zone supports abundant Sertularella sp. On the sandy bottom, Coccophora langsdorfi, attaching to embedded stones, is colonized by Amphisbetia pacifica and Zostera marinais epiphytized heavily by Clytia edwardsi.

As shown already the colony growth is markedly suppressed in the midlittoral zone. In the sublittoral zone the preferential settling of larvae on particular algae is most important in the establishment of particular association between hydroids and algae (NISHIHIRA, 1966, 1967a). Field experiments of algal selection by the larvae of Ser. miurensis showed that the settling larvae have strong algal selectivity. They settled preferentially on Sar. tortile, and other species of Sargassum. Some red algae received a few larvae but green algae were scarcely settled. These tendency are closely related to the field observation except that Sar. thunbergii received some larvae. The position of thallus on which the larvae settle is greatly influenced by the texture and countour of algal thalli (WiLliams, 1965, NishinIRA, 1967a). Almost all larvae settled on concave irregular surfaces as buds, origin of laminae, branches and air bladders. The number of settlement was not proportional to the amount of surface area of alga. The degree of branching or the irregularity of thallus could not explain satisfactorily the suitableness of Sargassum. A brief discussion about the factors influencing the settlement of the larvae has been given (NishinIRA, 1967a, 1968a, b). Chemical substance of the algae seems to be important for the promotion of larval settling (CRISP and Williams, 1960, Williams, 1964, Nishinira, 1968b). There are some observations that the chemical substance of algae inhibits the development of fouling organisms (Conover and Sieburth, 1964, Sieburth and Conover, 1965).

The algal preference of the larvae of Ser. miurensis was hihgly stable throughout the year. This stability of preference actually results in limiting the habitat of this species to a definite site on the shore. There are two prominent peaks in the seasonal trend of the larval settlement. The first peak in August is made by the larvae liberated by colonies on the old thalli which appeared in the previous summer. This larvaeproducing population soon declines with the old thalli, then the larval supply decreases in October. The second peak in November seems to be caused by the larvae from newly matured colonies originating from the larvae settled on the new thalli of the same year during the first peak of settlement. The relation between the high water temperature and season of the displacement of old thalli by the young ones which occurs in July to August, the behaviour type of the larvae and the stability in algal preference may guarantee the continuous and constant association between Ser. miurensis and Sar. tortile (NishinIRA, 1968c). The mechanisms of the delimitation of vertical distribution of Ser. miurensis on the shore is shown diagrammatically in Fig. 6.

Micro-distribution of Hydroids on the Thallus of Sargasso Algae:

KATO et al. (1961) reported that on Sargassum fulvellum, Obelia dichotoma distri- 


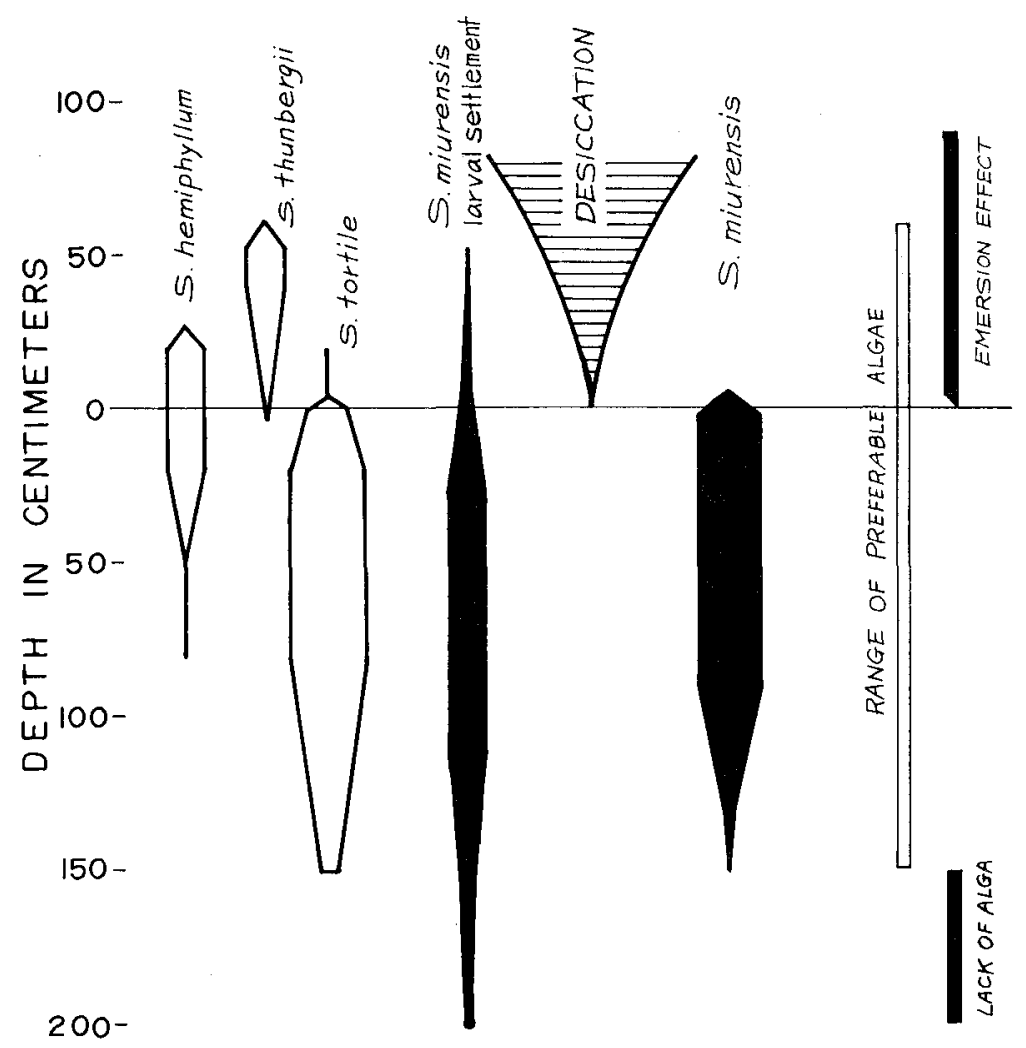

Fig. 6. Diagram showing the delimitation of vertical distribution of Sertularella miurensis on the shore. The larval supply ranges over the distribution of preferable alga and the range of adult population. The upper limit of distribution on the shore is delimited by the adverse emersion effect as desiccation. The lower limit of distribution is decided by the presence or absence factor of preferable algae. Below the low water spring tides the algal selection of settling larvae is most important.

buted densely in the rather peripheral portion of a definite stratum while Clytia volubilis was at the rather peripheral portion and distribute widly corresponding to the spindle from of the plants. Coryne uchidai occupied the upper half of the plant. On Sar. tortile, there were four strata in which the dominant species were from the proximal to the distal stratum respectively: Sertularella miurensis, Orthopyxis sp. and Sertularella, Sertularella and Coryne uchidai, and Orthopyxis and Sertularella. NisHIHIRA (1971) showed that both of Ser. miurensis and Orthopyxis platycarpa, when monopolied the thallus, were able to grow over the whole range of thallus. And other species also potentially can do, while Coryne is observed always occuping the distal half of the alga with or without other species. Sertularella sp. as shown in Fig. 4 occupies the proximal portion of Sar. thunbergii. On Sar. hemiphyllum and Sar. confusum and even in Sar. thunbergii, Orthopyxis can cover the entire thallus (NiSHIHIRA, 1971), but in Sar. tortile, Orthopyxis cannot cover the whole layer. 
These characteristic distributions may be brought about by the larval settlement on the definite portion of algae and definite colony growth may be important for the micro-distribution of the hydroids on the thallus. WILliams (1965) attributed the definite portion of attachment of Clava squamata on Ascophyllum nodosum to the behaviour of larva.

KAто et al. (1961) suggested the interspecific coaction among those hydroids resulting in the shift of normal portion of colonization in the case between Clytia and Obelia and decrease in the colony size or in the number of polyps in Sertularella and Orthopyxis. In the case of Ser. miurensis the larvae colonize preferentially the irregular surface as buds, and the young parts of the alga is preferred to the older part (NiSHIHIRA, 1968c). And hence no part of the young Sar. tortile is free from colonization of Ser. miurensis. Orthopyxis and Ser. miurensis shows tendency to avoid each other and this may be attributed to the segregated settlement of larvae and contradictory colony growth of these species. The smaller size of Ser. miurensis when co-existed with Orthopyxis is considered to be related to the younger age of colonies because in July to August a number of larvae settle and the upper part of Sar. tortile at that time is less densly colonized by hydroids. Orthopyxis usually occurs on the distal part of the thallus in such situation. Occupation of less densely colonized sites may be benefitial for the growth of new settlers (STEBbING, 1971).

Kato et al. (1962, 1963) showed experimentally that the interspecific coaction was observed during the development of the hydroid colony, Bougainvillia sp. dominating over each of Clytia and Orthopyxis to inactivate the colony of the latter two. Further by observing the regeneration from the mixed mass of tissue of each two hydroids among 6 species, the following order was recognized in the dominant subordination relationship:

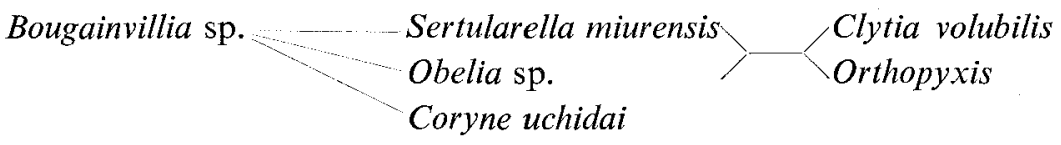

The least dominant species show the 'evasion growth' when co-existed with dominant species while Sertularella and Coryne remained as an atrophied colony being surrounded by the colony of the dominant. CHIBA and Kato (1966) showed that in Cladonema uchidae the extension in the colony, the abundance of the polyps and total length of stolon were inhibited by the presence of Bougainvillia sp., which was suspected to be caused by the metabolite of the latter species directly or indirectly.

In the field condition the extinction of subordinate species by the dominant species is actually seen (Nishinira, 1971). In late June, Sar. confusum were colonized by Clytia delicatula, Orthopyxis, Obelia geniculata and some Bougainvillia. Clytia is distributed from the base to the distal part as shown by КАто et al. (1961), while Bougainvillia colonized the central part. Orthopyxis occupied their own distribution areas. All of the species were segregated from each other and in healthy condition except some declining colonies of Clytia covered with Bougainvillia. About a month 
later, it was obvious that the colonies of Bougainvillia increased extremely; and on the contrary the other hydroids were almost extinguished from the alga. Only those colonies which did not contact with Bougainvillia survived. Sargassum confusum collected on mid July at Yunoshima near Asamushi carried Obelia and Clytia in good condition. Thus the extinction of hydroids by dominant species is actually occuring in the field condition as seen in the experimental conditions (KATo et al., $1962,1963,1964)$.

\section{General Discussion:}

There are three main phases in establishing the association between alga and hydroids and this is essential for the consideration of distributions of epiphytic hydroids. The most fundamental is the presence and persistency of algae, next most important is the presence of larval supply and then the settlement of larvae and colony formation after that. In every of these three phases there are some influential factors. They are summarized in Fig. 7. The association between Ser. miurensis and Sar. tortile was considered as an example, but it may have some general application.

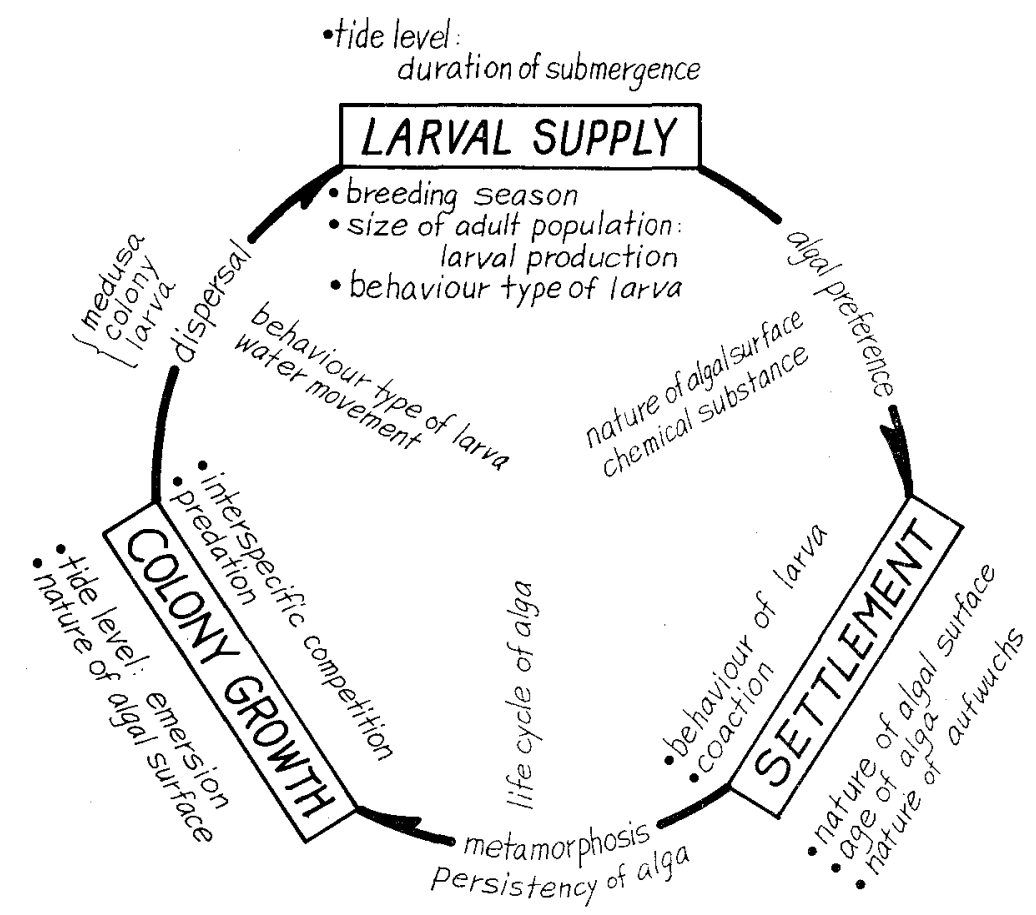

Fig. 7. Diagram showing the three phases in establishment of association between hydroids and algae with some influential factors in each phase. For further explanation see text.

a. Larval supply: Although the larva of Sertularella miurensis is of creeptype 
(KAKInUMA, 1961) they disperse rather widely. But the highest density was in the Sar. tortile forest where the amount of adult population is extremely large in relation to other vegetations (NISHIHIRA, 1967b, 1966, 1968c). It shows the concentric dispersal from the area of larval production. Namely the size of adult population is potentially most influential to the larval supply to the given area. The larval supply was also seen even in the midlittoral zone (NISHIHIRA, 1967b) where in normal condition few Ser. miurensis were seen. The lower extension of larval supply is rather common but in this situation absence of suitable algae such as Sar. tortile results in the absence of large adult population (Fig. 6). The time available for larval invasion is dependent on the duration of submergence of the growing site of algae. Thus the tide level of the shore has another meaning, which explains the less quantity of larvae in the midlittoral from another aspect (NISHIHIRA, 1967b).

b. Larval settlement: Within the area of sufficient larval supply, the algal preference of settling larvae is important to establish particular association between hydroid and alga. In the case of Ser. miurensis, planula in most cases settles on Sargasso algae, among which Sar. tortile is particularly preferable (NISHIHIRA, 1967a) and the algal selectivity is invariable throughout the year (NisHIHIRA, 1968c). The settlement is mostly restricted to the irregular surface of the thallus such as buds, origin of branches (NisHIHIRA, 1967a) and the young plant or the younger part of the old plant (NISHIHIRA, 1968c). Williams (1965) reported that Clava squamata settled on irregularities on Ascophyllum nodosum. The similar phenomena have been reported widely in Bryozoa (Ryland, 1962, Rogick and Croasdale, 1949) and other epiphytes.

In other species as Tubularia and Clytia the settlement is considered to be influenced by the development of periphyton community on the blades of Zostera (NisHIHIRA, 1968d). Older part of the blade bear more colonies. Shepherd and Watson (1970) also saw this on Ecklonia radiata. These may be due to the acquisition by the blade of the alga of a suitable surface film (NishiHIRA, 1968d) or may be due to a seasonal variation or decline in antibacterial activity by the alga (SIEBURTH and Conover, 1965). The similar phenomena have been widely observed in other group of epiphytic animals (CRISP and Williams, 1962, CrisP and Ryland, 1960, MEAdows and WILliams, 1963).

Thus the nature of algal surface, age of alga and nature of periphyton is important for the settlement of larva on the thallus especially in the position of larval settling.

The preferential settling on particular alga is induced by the nature of algal surface. In addition to that the chemical substance contained in the Sargasso algae, such as Sar. tortile, Sar. confusum and Sar. thunbergii were shown to promote the settlement of Coryne uchidai (NiSHIHIRA, 1968b) and the larvae of Ser. miurensis settle preferentially on the piece of these algae when added to the petri dish (KAKINUMA, 1961). The extract of some fucoids were also ataractive to the larvae of some bryozoa which were found usually on the attractive algae (CRISP and WILLIAMS, 1960) and also to the larvae of Spirorbis (WILLIAMS, 1964). 
It is interesting that the pelagic gulf weeds, Sargassum natuans and Sar. fluitans have branch tips which are virtually free of an epibiota when they are at the center of their distribution in the Sargasso Sea gyre (SIEburth and Conover, 1965, Conover and SieburTh, 1964). They attributed it to the highest tannins content in the distal tip of the thalli. They thought that tannins may be effective inhibitor to bacterial, algal and animal fouling organisms in young and actively growing tissues of at least the brown algae (Sieburth and Conover, 1965). ShEPHerd and WATson (1970) also attributed the general absence of epiphyte on brown algae to the presence of tannic substance. This description is interesting by comparison to the fact that among several species of Sargassum growing near Asamushi, Sar. horneri is usually free of epiphytic animals such as hydroids, Bryozoa and others. The reason is still unknown.

The settlement of Ser. miurensis is always abundant on the buds and the youngest part of the plant (Nishinira, 1967a, 1968c). Bryozoan Scrupocellaria reptans settles preferentially on the youngest part of a Laminaria fronds (RYLAND and STEBBinG, 1971) and Alcyonidium hirsutum settles preferentially on the younger parts of the fronds of Fucus serratus (cf. Stebing, 1971). Stebbing (1971) stated that selection of the younger parts for attachment is likely to enhance the chances of survival of an epiphyte or epizoite during the earliest and most critical stages of settlement and initial growth, for here competition for space is likely to be least intense. On Sar. tortile larvae settle preferentially on the younger, irregular parts as buds, etc. A bryozoan also prefers this position but they show the segregated occupation of bud where the density of both are large (NishiniRa, unpublished). Naturally the behaviour of larvae has large meaning. Interspecific coaction between settling larvae among hydroids and between bryozoan was also suggested (NISHIHIRA, 1967b, 1968c), which may results in the segregation between species in the micro-distribution on the thallus. In July to September almost all of the young thalli of Sar. tortile bear small colonies occupying the bud regions, the propagation is directed to the proximal part of the branch and soon it reaches main branch in October and almost all strata are covered by December. This preferential settlement of larvae has some important meaning for effective utilization of limited substratam.

The colony growth after the metamorphosis of settled larva is suported by the persistency of alga. Thus the long-lived algae is suitable for the epiphytic hydroids. Usually short-lived algae like some green algae are not epiphytized by hydroids (NishiHIRA, 1965, SHEPHERD and WATSON, 1970). The coincidence between breeding season of hydroid and life cycle of preferable alga as seen in Ser. miurensis and Sar. tortile is benefitial for the permanent association of the both species. Williams (1965) discussed the behaviour of crawling larvae of Clava squamata in relation with the restriction of distribution to the fronds of Ascophyllum nodosum. The larva lacks swimming phase and show photopositive behaviour in younger stage but negative in old stage. It was thigmokinetic and positive rheotactic.

c. Colony growth: As shown in Fig. 6, the emersion effect as desiccation on the 
survival or growth of settled larvae may delimit the upper distribution of Ser. miurensis on the thalli of Sar. thunbergii which is potentially preferable. Similar relations were suspected in some bryozoans and Ascophyllum nodosum or Fucus spiralis (RYLAND, 1959b, 1962, CRisP and Williams, 1960).

Within the range free from the danger of emergence, the growth form and nature of algal surface have great importance to the propagation of colony, especially the growth direction of stolons and size of polyps (NishiHIRA, unpublished). KaTo et al. (1961) suspected the interspecies coaction between hydroid species colonizing together the same thallus in the shift of colonizing position or decrease of colony size and number of polyps in subordinate species. Experimentally they confirmed their assumption (Kato et al. 1962, 1963, 1964, CHIBA and KATo, 1966). An athecate hydroid, Bougainvillia sp. was donimate over all the other 7 species tested. This species, when cultured together with other species, always extinguish other species. Consequently the interspecies interaction may be important for microdistribution of epiphytic hydroids on a thallus. The luxuriant growth of Bougainvillia actually extinguished the other species in the field condition (NISHIHIRA, 1971). The microdistribution of the epiphytes on the thallus is primarily decided by the larval settlement and the growth of colony after that. Throughout these two phases the interspecies interaction is of great importance (Nishinira, 1967b, 1971, StEbBing, 1971).

There are some predators or parasite of Ser. miurensis and other hydroids, but at present the role of predation in the determination of ecological distribution is not known.

d. Dispersal: The dispersal of hydroids is done by means of three ways, namely 1: medusa, 2: larvae, and 3: colonies attaching to the floating algae. The second and the third are seen in Ser. miurensis (Nishinira, 1967b), and the latter may be effective for long-distance dispersal. Ser. mitrensis does not produce medusae. Although the larvae of Ser. miurensis is creeping type the larval dispersal is relatively wide, while the concentration is seen in the area of adult population.

The coincidence of life cycle of two organisms and seasonal stability of algal preference of settling larvae, preferential settlement on the younger buds of the plant, sublittoral growth of Sar. tortile and great persistency of thallus; all of them may be benefitial to the continuous association between these two organisms and hence the ecological distribution of Ser. miurensis on the shore. Consequently once Ser. miurensis has settled on Sar. tortile in a new area on the suitable level on the shore the distribution in that place may continue.

\section{Summary}

Seasonal observations of the hydroid, Sertularella miurensis, associating with Sargassum tortile growing in the sublittoral fringe and the field experiments of transplanting hydroid colonies to various situations showed that the upper extension of 
the distribution of Ser. miurensis on the shore is delimited by the emersion effect. The time of day when the low tides occur and duration of emersion were important for the mortality of hydroids in the upper margin of their distribution range. Desiccation seemed to be important. By colonizing the proximal part of the algal thalli, however, a hydroid occupies the midlittoral zone.

Within the range free from such an adverse emersion effect, as in sublittoral zone, the ecological distribution is largely influenced by the nature of algal preference of settling larvae. Algal selection by the hydroid larvae is most important in determing the ecological distribution, which is established by the continuous association between algae and hydroids. In general Sargasso algae are suitable substrara for hydroids.

Some hydroids occupy a definite portion of the algal thallus and it seems to be explained by the nature of larval behaviour and by the interspecies interaction between settling larvae and interspecies competition for space among the epiphytic hydroids in the process of colony growth.

A general discussion was given as to 1: delimitation of upper range of distribution on the shore, 2: ecological distribution of epiphytic hydroids and the role of algal selection of settling larvae, 3: microdistribution of hydroids on the thallus of Sargasso algae, and 4: interspecies relationship in the microdistribution.

\section{REFERENCES}

Chiba, Y. \& M, Kato, 1966. Interspecific relation in the colony formation among Bougainvillia sp. and Cladonema radiatum (Hydrozoa, Coelenterata). Sci. Rep. Tohoku Univ., Ser. 4, (Biol.), 32: 201-206.

Conover, J. T. \& J. McN. Sieburth. 1964. Effect of Sargassum distribution on its epibiota and antibacterial activity. Botanica Marina, 6: 147-157.

CONNELL, J. H. 1961a. The influence of interspecific competition and other factors on the distribution of the barnacle Chthamalus stellatus. Ecol., 42: 710-723.

___ 1961b. Effects of competition, predation by Thais lapillus, and other factors on natural populations of the barnacle Balanus balanoides. Ecol. Monogr., 31: 61-104.

— 1970 . A predator-prey system in the marine intertidal region. I. Balanus glandula and several predatory species of Thais. Ibid., 40:49-78.

Crisp, D. J. \& J. S. RYLAND. 1960. Influence of filming and of surface texture on the settlement of marine organisms. Nature, Lond., 185:119.

Crisp, D. J. \& G. B. Williams. 1960. Effect of extracts from fucoids in promoting settlement of epiphytic Polyzoa. Ibid., 185: 1206-1207.

Foster, B. A. 1971. On the determinants of the upper limit of intertidal distribution of barnacles (Crustacea: Cirripedia). J. Anim. Ecol., 40:33-48.

FOSTER, B. A. 1971. Desiccation as a factor in the intertial zonation of barnacles. Mar. Biol, 8: 12-29.

HoshiaI, T. 1965. Synecological study of intertidal community. VI. A synecological study on the intertidal zonation of the Asamushi coastal area with special reference to its re-formation. Bull. Mar. Biol. Stat. Asamushi, 12: 93-126.

Kakinuma, Y. 1961. Investigations on the life cycle of some hydrozoans and scyphozoans from near Asamushi. J. Aomoriken Biol. Soc., 4: 10-17 (In Japanese).

Kato, M., Nakamura, K., Hirai, E. \& Y. Kakinuma. 1961. The distribution pattern of Hydrozoa on sea weeds with some notes on the so-called coaction among hydrozoan species. Bull. Mar. 
Biol. Stat. Asamushi, 10: 195-202.

— 1962 . Interspecific relation in the colony formation among some hydrozoan species. Ibid., $11: 31-36$.

Kato, M., Hirai, E. \& Y. Kakinuma. 1963. Laboratory experiments on the interspecific relation in the colony formation of some hydrozoan species. Ibid., 11: 87-89.

____ 1964. Further experiments on the interspecific relation in the colony formation among some hydrozoan species. Sci. Rep. Tohoku Univ., Ser IV (Biol.)., 29: 317-325.

NaGao, Z. 1965. Studies on the development of Tubularia radiata and Tubularia venusta (Hydrozoa). Publ. Akkeshi Mar. Biol. Stat., 15: 9-35.

NishiHIRA, M. 1965. The association between Hydrozoa and their attachment substrata with special reference to algal substrata. Bull. Mar. Biol. Stat. Asamushi, 12: 75-92.

___ 1966. Ecological distribution of epiphytic Hydrozoa on the Tsuchiya coast near the Marine Biological Station of Asamushi. Ibid., 12: 179-205.

$\ldots, 1967 \mathrm{a}$. Observations of the algal selection by the larvae of Sertularella miurensis in nature. Ibid., 13: 35-48.

__ , 1967b. Dispersal of the larvae of a hydroid, Sertularella miurensis. Ibid., 13: 49-56.

- $1968 \mathrm{a}$. Experiments on the algal selection by the larvae of Coryne uchidai STECHow (Hydrozoa). Ibid., 13:83-89.

- $-1968 \mathrm{~b}$. Brief experiments on the effect of algal extracts in promoting the settlement of the larvae of Coryne uchidai STECHow (Hydrozoa). Ibid., 13: 91-101.

- $1968 \mathrm{c}$. Dynamics of natural populations of epiphytic Hydrozoa with special reference to Sertularella miurensis STECHow. Ibid., 13: 103-124.

—_ $1968 \mathrm{~d}$. Distribution pattern of Hydrozoa on the broad-leaved eelgrass and narrow-leaved eelgrass. Ibid., 13: 125-138.

-, 1969. Ecological studies of epiphytic Hydrozoa. Ibid., 13: 183-186.

, 1971. Colonization pattern of Hydrozoa on several species of Sargassum. Ibid., 14: 99-108.

Rogick, M. D. \& H. Croasdale. 1949. Studies on marine bryozoa. III. Woods Hole region Bryozoa associated with algae. Biol. Bull. Woods Hole, 96: 32-69.

Ryland, J. S. 1959. Experiments on the selection of algal substrates by Polyzoan larvae. J. Exp. Biol., 36: 613-631.

-, 1962 . The association between Polyzoa and algal substrata. J. Anim. Ecol., 31: $331-338$.

Ryland, J. S. \& A. R. D. Stebing. 1971. Settlement and orientated growth in epiphytic and epizoic bryozoans. Proceedings of IVth European Marine Biology Symposium, pp. 105-123.

ShePherd, S. A. \& J. E. WATson. 1970. The sublittoral ecology of West Island, South Australia: 2. The association between hydroids and algal substrate. Trans. Roy. Soc. S. Australia, 94: 139_ 146.

Steburth, J. McN, \& J. T. Conover. 1965. Sargassum tannin, an antibiotic which retards fouling. Nature, Lond., 208: 52-53.

Stebing, A. R. D. 1971. The epizoic fauna of Flustra foliacea (Bryozoa). J. Mar. Biol. Ass. U. K., $51: 283-300$.

Williams, G. B. 1964. The effects of extracts of Fucus serratus in promoting the settlement of larvae of Spirorbis borealis (Polychaeta). Ibid., 44: 397-414.

, 1965. Observations on the behaviour of the planulae larvae of Clava squamata. Ibid., $45: 457-273$.

\section{DISCUSSION}

TOMIYAMA: Is there any hydroid growing on green algae? 
Nrshthira: Yes. In the Asamushi area, two species of green algae, Ulva pertusa and Codium fragile, were colonized by 7 species of hydroids. Generally, green algae are unpreferable substrates for epiphytic animals. In the Okinawa area, some green algae such as Halimeda spp. and Caulerpa spp. offer good attachment sites for hydroids. Generally, hard and long-lived thalli are good substrates for hydroids.

CHENEY: Is the seasonality in growth of sublittoral species of Sargassum anyway correlated with known patterns or seasonality of hydroid breeding season?

NiSHIHIRA: Yes. The coincidence between the breeding season of hydroid, Sertularella miurensis, and the life cycle of preferable alga, Sargassum tortile, is important for the permanent and continual association between them. There are two prominent peaks in the seasonal abundance of larval settlement, one in August and another in November. Displacement of algal thalli between old and new young thalli occurred in August when the settlement of larvae was most abundant. Larvae select young plant and younger part of the plant. Consequently, the young plant receives majority of planula settlement. The colonies originating from these newly settled larvae grow and mature in November and hence they produce many larvae; this is the second peak of larval settlement. In this season, the distal part of algae which is free from colonization receives many settling larvae. And finally, the entire strata of algal thalli is colonized heavily by Sertularella miurensis.

EDWARDS: Js it known whether epiphytic hydroids feed on motile spores of algae?

NishiHIRA: I am not certain with this problem. I have never conducted any observations on the feeding behavior in Sertularella miurensis. But it is important to know this problem for the comprehension of hydroid population in the biological community in Sargassum belt. 